\title{
MANIFESTASI PRAGMATISME PENDIDIKAN POLITIK (Analisis Resepsi pada Komodifikasi Berita Selebriti Politisi)
}

\author{
Wahyuni Choiriyati \\ Fakultas Ilmu Komunikasi Universitas Gunadarma \\ Jalan Margonda Raya No. 100 Depok 16424, Jawa Barat \\ Email: choiri@staff.gunadarma.ac.id
}

\begin{abstract}
Celebrity politicians and mass media attract public's attention. News about celebrity politicians become a commodity for mass media and it increases the popularity of the celebrity politicians. This creates relationships of capitalism motion in mass media that has penetrated digital media. Focus of this study is public meanings about celebrity politicians on online media. Using qualitative methods and in-depth interviews, this study shows how the practice of the commodification content of celebrity politicians and mass media was interwoven. The result also shows that the practice of the commodification of online media content in the fabric of pragmatism has no exercise of political education efforts through the media. Media were supposed to carry out their duties in an effort to educate the public actually shirking its duty. Practice capitalism in media shallow public thinking on the political dynamics in Indonesia. The struggle between the interests of the media as an institution of political education and vice versa become imaging agents on the political role. This siltation is the embryo of the normalization of news construction power that led towards pragmatism.
\end{abstract}

Keywords: Politicians Celebrities, receptions Analysis, Online Media

\begin{abstract}
Abstrak
Politisi selebriti dan media massa menjadi sebuah jalinan yang menarik perhatian banyak pihak. Pemberitaan mengenai politisi selebriti menjadi sebuah komoditas bagi media massa sekaligus meningkatkan popularitas politisi selebriti tersebut. Hal ini kemudian menciptakan hubungan gerak kapitalisme dalam praktik media massa yang telah merambah media digital. Pemaknaan publik mengenai pemberitaan politisi selebriti di media online menjadi focus penelitian ini. Menggunakan metode kualitatif dan wawancara mendalam, penelitian ini menunjukkan bagaimana praktik komodifikasi isi pemberitaan politisi selebriti serta jalinan pragmatisme media massa. Hasil menunjukkan bahwa praktik komodifikasi isi media online dalam jalinan pragmatism menunjukkan tidak dijalankannya upaya pendidikan politik melalui pemberitaan media. Media yang seharusnya menjalankan tugasnya sebagai upaya mendidik public justru melalaikan tugasnya. Praktik kapitalisme di media mendangkalkan pemikiran public mengenai dinamika politik di Indonesia. Pergulatan antara kepentingan media selaku lembaga edukasi politik dan sebaliknya menjadi agen pencitraan atas peran politik yang semakin dangkal. Pendangkalan inilah merupakan embrio dari normalisasi kekuatan konstruksi berita yang berujung ke arah pragmatisme.
\end{abstract}

Kata Kunci: Politisi Selebriti, Analisis Resepsi, Media Online 
Wahyuni Choiriyati, Manifestasi Pragmatisme Pendidikan Politik...

\section{PENDAHULUAN}

Kisah sukses artis yang menang di beberapa Pemilihan Kepala Daerah atau menjadi anggota Dewan Perwakilan Rakyat menjadi daya tarik baru bagi artis saat ini. Langkah artis ini dapat dipahami mengingat sebelumnya telah terjadi prelude kesuksesan para artis pendahulu. Hampir semua partai besar dipastikan memasang artis-artis populer dalam daftar calon legislatifnya. Turner dalam Understanding Celebrity (2004) mengatakan bahwa selebriti dapat dikategorikan sebagai 'property' dalam arti menjadi aset finansial bagi pihakpihak yang mau memanfaatkan mereka dalam konteks komersial, demi memperoleh keuntungan. Pragmatisme partai terhadap kandidat tanpa memilah siapa mereka, sudah disampaikan sejak lama. Bone dan Ranney (1976) misalnya, mengatakan bahwa perkembangan partai besar di Amerika tidak lagi menganut ide yang disampaikan oleh Edmund Burke, dimana partai politik adalah kumpulan orang-orang yang berusaha untuk mempromosikan sebuah ide dengan tujuan memenuhi kepentingan dan interest publik.

Hal ini senada dengan penelitian yang dilakukan Couldry dan Markham (2007) dalam Celebrity Culture and Public Connection : Bridge or Chasm?. Kedua peneliti menerapkan perpaduan metode kualitatif dan kuantitaf dengan multiple indepth interview dan survey telepon melalui responden yang menggunakan media cetak sebagai referensi peningkatan kesadaran politik dari artis-artis Amerika sebagai bagian dari gimmick politik sebuah partai atau elit tertentu. Temuan penelitian lebih menjelaskan bahwa responden cenderung menangkap simbol-simbol keartisan daripada pesan politiknya, karena kredibilitas artis selaku komunikator politik diragukan oleh kebanyakan responden. Bukti empiris lain merujuk pada hasil penelitian Richard Schickel (1985) yang menguji proses politik di Amerika. Schickel melakukan pemetaan atas partisipasi dalam rangkaian pemilihan presiden Amerika Serikat; Eisenhower, Kennedy, Carter dan Reagen. Penelitiannya memperdebatkan bahwa kampanye pemilihan saat itu berlangsung sederhana laiknya "sebuah kontes diantara kepribadian", bahkan isu yang berkembang dalam pemilihan itu tidak lebih hanya sekedar peristiwa untuk menguji daya tarik personal dari pesaingnya. Reagen adalah mantan bintang film yang merupakan politisi terkenal Amerika yang lolos menjadi presiden Amerika.

Pemberitaan seputar kehadiran Rhoma Irama, Marissa Haque dan Angelina Sondakh sebagai politisi hasil dari Pemilu tahun 2004 yang berasal dari kalangan selebriti merupakan potret gambaran dari riset-riset tersebut. Pada tahun 2008 pasangan Ahmad Heryawan dan aktor film Dede Yusuf memperoleh kemenangan dalam Pilkada Jawa Barat. Situasi ini mengukuhkan telah datangnya suatu era baru dalam demokrasi di Indonesia. Fenomena "Celebrity Politics" mulai dikenal dalam terminologi Ilmu Politik setelah para bintang film, pemain sinetron, komedian, dan penyanyi terjun ke dunia politik. Mereka bukan sebagai 
penghibur panggung kampanye atau pengumpul suara. Para selebriti mulai serius mengejar kursi jabatan publik seperti anggota DPR, bupati, walikota, gubernur atau presiden.

Beberapa mekanisme pemilu langsung pertama yang dilakukan berdasarkan sistem semi distrik dipandang menguntungkan bagi mereka. Hal ini karena tidak hanya nama wakil rakyat yang ditulis dikertas suara, namun juga mulai dipampangkan foto-foto kandidatnya. Pada Pemilu 2014, banyak selebriti yang masuk ke kancah politik, menggunakan popularitasnya untuk mengumpulkan dukungan. Para kompetitor politisi lainnya yang tidak dikenal rakyat tibatiba mendapatkan saingan hebat dengan munculnya wajah-wajah para politisi selebriti ini, sosok yang lebih banyak dikenal sehingga lebih populer di mata para calon pemilih. Hal tersebut tercermin pada Pemilu 2014. Terdapat hampir 40 artis yang mencalonkan diri, namun berdasarkan Surat Keputusan (SK) KPU Nomor 416/Kpts/KPU/2014 tentang penetapan perolehan kursi partai politik dan calon anggota DPR terpilih, setidaknya ada 15 artis dan 3 atlet yang berhasil lolos ke Senayan sebagai legislator.

Partai Amanat Nasional (PAN) menjadi partai yang paling banyak menyumbang artis ke Senayan. Fenomena terpilihnya selebriti perempuan ke panggung politik baik di Indonesia maupun di negara-negara lainnya yang demokratis memperlihatkan kekuatan selebriti mampu untuk menggalang massa dan dipergunakan untuk menjaring dukungan bagi partai politik. Selebriti dijadikan produk politik, sebagai kandidat untuk ditawarkan bagi pasar pemilih melalui strategi-strategi political Marketing. Posisi tawar yang besar bagi para artis untuk masuk dalam bursa politik menciptakan sebuah adagium "politik tidak selalu garang" namun bisa berubah dengan nuansa yang lekat dengan simbol "cantik, ganteng, populer" atau diibaratkan seperti menghadirkan sebuah opera baru dengan pentas yang berbeda.

Hadirnya aktor politik selebriti senada dengan Bauer (2010) yang secara implisit menyampaikan bahwa sosok selebriti mampu merubah wajah panggung politik. Lebih jauh politik dilihat sebagai aktivitas untuk mengintegrasikan orang-orang dalam suatu komunitas dengan ide dan gagasan yang spesifik tentang cara yang seharusnya dipergunakan dalam interaksi dan dinamika sosial. Dengan kata lain, politik pada dasarnya akan mempengaruhi bentuk dan pola interaksi sosial di masyarakat. Merujuk pada Undang-undang No.12 tahun 2003 mengenai kampanye media, Pemilu DPR, DPRD dan DPD, pada pasal 73, ayat 1 dan 2 dijelaskan bahwa :

1) Media elektronik dan media cetak memberikan kesempatan yang sama kepada peserta pemilu untuk menyampaikan tema dan materi kampanye pemilu.

2) Media elektronik dan media cetak wajib memberikan kesempatan yang sama kepada peserta pemilu untuk memasang iklan pemilu dalam rangka kampanye. 
Penjelasan ayat 2 pasal 73 ini adalah peserta pemilu tidak boleh menggunakan kesempatan untuk memasang iklan yang tidak digunakan oleh peserta pemilu lainnya. Beberapa masalah timbul di lapangan ketika definisi tentang 'kesempatan yang sama' tidak selalu berbanding lurus, mengingat perbedaan kondisi keuangan serta akses yang dimiliki oleh partai politik ke media lain. Dalam situasi inilah terjadi praktek-praktek pemberitaan yang berat sebelah yang seringkali dicurigai sebagai konspirasi media.

Sejatinya praktek liputan atas berita politik yang tidak seimbang telah melanggar Deklarasi Windhoek (1991) Unesco. Deklarasi ini memuat sikap pers yang independen yang menegaskan bahwa pers bebas dari kontrol pemerintah, kepentingan-kepentingan politik atau ekonomi atau dari pengontrolan bahan-bahan dan infrastruktur yang penting bagi produksi dan distribusi suratkabar, majalah dan terbitan periodik. Berangkat dari latar belakang di atas, peneliti melalui serangkaian analisis permukaan, menemukan pemberitaan politik yang mengarah pada konstruksi selebriti selaku politisi dalam berita politik media online tanah air. Pemilihan Media online sebagai bagian riset media berkontribusi pada pendangkalan pendidikan politik melalui tampilan pemberitaan artis seputar pemilu dan sosialisasi politik di daerah pemilihannya.

Kenyataan yang berkembang di masyarakat dewasa ini adalah terjadinya pergeseran cara pandang terhadap dunia politik. Lahirnya cara pandang ini dikonstruksi juga oleh media kita. Pragmatisme mulai dirasakan sebagian masyarakat kita karena peran aktor politik yang hendaknya dipegang aktor politik dengan kompetensi dan kredibilitas berpolitik mulai digantikan kelompok yang lebih populis dan komersial tanpa didukung latar belakang pengetahuan berpolitik yang baik. Berbagai sumber informasi dapat dengan mudah diperoleh melalui media online saat ini. Sinyalemen ini berkembang sejalan dengan realitas yang muncul dengan makin banyak jumlah artis terjun sebagai politisi instan. Fenomena tersebut adalah konsekuensi logis dari sejumlah peraturan yang longgar dalam menjaring anggota legislatif. Merujuk pada Undang-undang No. 10 tahun 2008, di dalamnya tertuang syaratsyarat pengajuan calon anggota legislatif yang tidak mempersyaratkan kemampuan legislasi, kinerja dan kompetensi politik.

Dalam Pilkada serentak 9 Desember 2015 lalu, publik tanah air juga dikejutkan oleh vokalis Grup Band Ungu, Pasha, yang berhasil diusung PAN dan PKB. Berdasarkan hasil hitung cepat yang dilakukan Lingkaran Survei Indonesia (LSI), pasangan Hidayat - Sigit Purnomo alias Pasha Ungu memperoleh $37,76 \%$ suara. Mereka sudah dipastikan sebagai pasangan pemenang dalam pemilihan Walikota dan Wakil Wali Kota Palu Sulawesi Tengah.

Masyarakat telah melihat bahwa kehidupan politik bukan lagi kehidupan yang sakral. Masyarakat sudah 
mengetahui bahwa politisi hanyalah satu di antara begitu banyaknya profesi (Firmanzah, 2007). Dengan kata lain maraknya penempatan artis dalam setiap partai politik saat ini masih dalam taraf sebagai figuran politik atau sekedar pengumpul suara (votegetter) dalam konstruksi masyarakat kita. Persaingan antar partai dan kontestan (calon bupati, gubernur, walikota) menjadi sebuah ciri khusus dalam pesta pemilihan di Indonesia. Realitanya adalah partai atau kontestan yang harus berhadapan langsung dengan publik sebagai pemilih menempatkan pemilih sebagai basis, acuan dan target yang menjadi satu-satunya penentu kemenangan. Perebutan simpati masyarakat dianggap sebagai modal utama meningkatkan kemenangan dalam persaingan, akibatnya pemilihan figur populer menjadi platform utama dalam persaingan politik. Berpijak pada pemaparan data diatas, tulisan ini memaparkan pendangkalan dalam proses rekrutmen politik secara masif hampir semua partai besar di Indonesia. Melalui studi pemaknaan, penelitian ini berusaha memaparkan kecenderungan pendangkalan proses pendidikan politik berdasar pada dampak berita politik media online.

Sebagaimana diutarakan oleh Robert dan Agustinus yang mendeskripsikan bahwa inilah zaman ketika politik menjadi semakin rumit oleh pengaruh media massa dan kapitalisme kontemporer, dan teori-teori lama tidak cukup lagi untuk menjawabnya. Alangkah senjangnya ilusi liberalisme tentang rasionalitas pemilih dengan kenyataan empiris pilkada yang dimenangkan lewat 'senyum'(Robert dan Agustinus, 2008). Munculnya citra demikian dibangun oleh media massa yang kerap menempatkan dasar jurnalistik dan jurnalisme sebagai hal yang sama. Terminologi konseptual atas keduanya seringkali dipakai sebagai istilah secara bergantian. Jurnalistik sebagai ketrampilan teknis dapat dipergunakan untuk berbagai tujuan, mulai dari penghasutan hingga pornografi. Akibatnya teknik jurnalistik dapat digunakan untuk kepentingan pragmatis komunikator. Dalam situasi seperti inilah komodifikasi informasi pers terlebih berita-berita politik merupakan bentuk-bentuk yang dianggap umum dalam teknik jurnalistik. Berkaitan dengan hal tersebut, persoalan yang coba dikaji dalam penelitian ini meliputi bentuk pragmatisme pendidikan politik yang terjadi dalam komunikasi politik di Indonesia serta bentuk komodifikasi isi terjadi dalam pragmatisme pendidikan dan sosialisasi politik di Indonesia melalui pemberitaan di media online sindonews dan tempointeraktif.

\section{METODE PENELITIAN}

Paradigma penelitian yang digunakan dalam penelitian ini adalah paradigma kritis dengan pendekatan kualitatif. Penelitian yang bersifat kritis berusaha mendekonstruksi struktur yang opresif. Teori kritis dalam Littlejohn (1996), dibedakan dalam dua varian. Terbagi menjadi teori kritis strukturalis dan pasca-strukturalis. Kritis Strukturalis melihat bahwa strukturstruktur sosial yang menindas itu bersifat nyata, meskipun penindasan itu 
kadang-kadang tersembunyi dan luput dari kesadaran kebanyakan orang. Lebih jauh, littlejohn menguraikan bahwa struktur bersifat opresif dan menindas. Di lain pihak, varian kritis pascastrukturalis memandang tidak terdapat realitas atau makna sentral. Penindasan dalam struktur hanya berlangsung sementara. Apabila terdapat perjuangan menggugat struktur, maka yang muncul adalah perjuangan tunggal yang bersifat cair. Teori Kritis biasa digunakan untuk membongkar struktur teks dominan dari media yang ada di masyarakat.

Dalam Progress and Pragmatism,

William John Dewey (1974)
menguraikan pokok pikiran pragmatisme sebagai istilah yang berasal dari kata Yunani pragma yang berarti perbuatan (action) atau tindakan (practice). Isme di sini sama artinya dengan isme-isme lainnya, yaitu berarti aliran atau ajaran atau paham. Dengan demikian Pragmatisme itu berarti ajaran yang menekankan bahwa pemikiran mengikuti tindakan. Suatu teori atau hipotesis dianggap oleh Pragmatisme benar apabila membawa suatu hasil. Dengan kata lain, suatu teori itu benar kalau berfungsi. Dengan demikian Pragmatisme dapat dikategorikan ke dalam pembahasan mengenai teori kebenaran (theory of truth), sebagaimana yang nampak menonjol dalam pandangan William James, terutama dalam bukunya The Meaning of The Truth (1909).

Ilmu politik mengabdi pada masyarakat sehingga ia menjadi sarana untuk mencerdaskan dan mensejahterakan umat manusia dalam kehidupan bernegara dan berdemokrasi.
Namun seringkali nilai-nilainya dikaburkan karena inti ilmu ditentukan oleh derajat penerapan praktis dari ilmu itu sendiri. Pandangan inilah yang terangkai dari pemikiran diatas. Kebenaran dalam konteks ini merupakan suatu ide yang hanya berlandaskan pada efek-efek praktis, hal ini tercermin bagaiman pola pemberitaan pesohor yang seringkali mengambil esensi dasar dari informasi politik yang sesungguhnya karena terenggut logika ekonomi politik yang lebih tendens pada politik instan yang praktis. Berpijak pada Stafford terkait profesi selebriti menjadi politisi bukanlah perkara mudah. Branston dan Stafford (2006) dalam bukunya menjelaskan berita selebriti saat ini telah menjadi bagian dari kesehaharian kita. Eksistensi mereka telah menyebar dalam komunitas publik. Lain halnya dengan Wyatt (1994) yang menguraikan bahwa studi-studi mengenai media dan Film telah lama mengeksplorasi bentukbentuk sinema yang mengkonstruksi selebritas seorang artis.

Selebritis umumnya membenarkan bahwa kehidupan mereka dikonstruksikan melalui skenario yang selama ini mereka perankan dari satu peran ke peran yang lain. Pemikiran dari beberapa ahli diatas menunjukkan konstruksi atas selebritas seseorang tidak lepas dari keterlibatan ideologi, struktur sekaligus agen yang saling mengukuhkan satu sama lain. Maka representasi identitas kepopuleran seseorang tidak lepas dari kepentingan pemilik modal yang memanfaatkan mereka sebagai alat persuasi untuk mengakumulasi modal. Persuasi dapat 
dilakukan melalui propaganda seni dan budaya baik film atau gaya hidup selebritas mereka. Sebuah refleksi bagi kita, ketika artis memasuki era yang berbeda sama sekali dari panggung sandiwara menuju pentas politik, dari arena hiburan menuju arena pergulatan sosial dan penderitaan.

Secara teknis atau "fisik", media online adalah media berbasis telekomunikasi dan multimedia (komputer dan internet). Termasuk kategori media online adalah portal, website (situs web, termasuk blog), radio online, TV online, dan email. Berita online atau diistilahkan sebagai portal merupakan media yang paling sering dibaca saat ini dibanding media cetak konvensional. Melalui tulisan ini, terdapat pengungkapan pemaknaan pada portal berita politik yang mengarah pada pragmatism bukan pada esensi proses pendidikan politik dan peningkatan kesadaran partisipasi pemilih. Tulisan ini menyandarkan pragmatisme dengan pendekatan komodifikasi pada varian ekonomi politik komunikasi Vincent Mosco (1996).

Mosco (1996) mengklasifikasikan komodifikasi dalam komodifikasi isi (intrinsik), komodifikasi khalayak dan komodifikasi cybernetics sebagai proses mengatasi kendala ruang dan waktu. Komodifikasi khalayak menjadi bagian integral dari komodifikasi isi dalam menopang survival institusi media. Dalam praktek terhadap nilai-nilai budaya setempat maka relasi itu akan saling menguatkan terhadap isi yang hendak dibangunnya sehingga keterlibatan khalayak menjadi perlu dipertimbangkan secara mutualistik. Komodifikasi khalayak mengaggregasikan berbagai unsur dalam sebuah kepentingan yang lebih utama yaitu keuntungan bagi medianya oleh karena proses tersebut menjadikan media berada dalam tujuan utama dalam hal keuntungan kapitalnya.

Komodifikasi isi yang dipahami sebagai proses mengubah pesan dari sekumpulan data ke dalam sistem makna yang kemudian dapat dipasarkan, merupakan fokus dari kajian ini. Penentuan komodifikasi isi dalam penelitian ini didasarkan pada manifestasi praktek eksposure terhadap selebriti yang beralih profesi ke politisi menjadikan berita politik sebatas nilainilai komersial dalam pendidikan politik. Maka praktek surat kabar sebagai manifestasi pragmatis dan aktualisasi dari nilai-nilai komersil yang menekankan selebriti sebagai komoditi, dipahami sebagai suatu proses komodifikasi yang sangat strategis. Umumnya tulisan, artikel berita sebagai produk media cetak dipasarkan sebagai bagian yang disejajarkan dengan iklan dalam suatu paket yang bisa dijual.

Situasi sosial yang mengelilingi pembaca, penonton, pendengar akan mambawa mereka untuk mengadopsi teks media dari sudut pandang yang berbeda. Hall (1973) menurunkan dan mengelaborasi gagasan Parkin mengenai 3 sistem pemaknaan dasar yang digunakan individu untuk menafsirkan atau memberi respons terhadap persepsinya mengenai kondisi dalam masyarakat. Ia menunjukkan bahwa 3 sistem tersebut terkait dengan cara pembaca men-decode teks media. 
Wahyuni Choiriyati, Manifestasi Pragmatisme Pendidikan Politik...

Ketiga sistem itu adalah sebagai berikut:

1) Sistem Dominan (Dominant Readings), merupakan salah satu sistem atau kode yang dihasilkan ketika situasi sosial yang mengelilingi pembaca menyerupai preferred readings.

2) Sistem Subordinat (Negotiated Readings), merupakan sistem atau kode yang dinegosiasikan. Dalam hal ini, nilai-nilai dominan dan struktur yang ada dalam preferred readings diterima, namun nilai-nilai tersebut digunakan sebagai penegasan bahwa situasi sosial yang ada perlu diperbaiki.

3) Sistem Oposisional (Oppositional Readings), merupakan sistem atau kode yang menolak versi dominan dan nilai-nilai sosial dari preferred readings. Pembaca menempatkan pesan dalam sistem makna yang secara radikal berlawanan dengan makna dominan.

Melalui ketiga sistem di atas peneliti merumuskan beberapa kategori pembaca berita politisi selebriti untuk ditafsirkan secara komprehensif. Kemudian mengelompokkan kategori pembaca sesuai penafsirannya atas nilai dominan.

Pengumpulan data dan bahan empiris dilakukan melalui wawancara mendalam (indepth Interview) sebagai data primer. Teknik wawancara yang dipergunakan adalah wawancara dengan pedoman standar yang terbuka agar subyek penelitian dapat berbicara dengan bebas (Denzin dan Lincoln, 1994). Data sekunder menggunakan studi literatur dalam media baru, yaitu dua situs tempo.com dan sindonews yang berisikan pemberitaan selebriti politisi periode 20013-2014, yang memuat masa kampanye sebelum Pemilu 2014. Informan dipilih dengan teknik purposeful sampling. Keempat informan yang berasal dari Jakarta, Bogor, Depok, Tangerang (mewakili Jabodetabek). Temuan hasil wawancara mendalam dianalisis dengan menggunakan análisis tematik (thematic analysis) dari Flick et al (2004). Peneliti akan mengidentifikasi dan mengkombinasikan data yang terpola secara spesifik baik dalam tingkat termanifestasi maupun tingkat laten sehingga didapatkan pemaknaan pembaca terhadap pemberitaan yang mensirkulasikan politisi selebriti serta faktor-faktor kontekstual yang melatarbelakanginya.

\section{HASIL DAN PEMBAHASAN}

Observasi fenomena selebriti dianggap hal yang wajar bila menyandarkan pada sistem yang digunakan memproduksi label selebriti dalam dunia hiburan sekaligus industri olahraga dan ternyata memiliki kemiripan pola dengan label dan poduksi identitas publik figur dalam ranah politik. Kesuksesan adalah kebutuhan bagi seorang politisi dalam membangun ruang publiknya yang diartikan bahwa telah tercapai konvensi antara seorang selebriti dengan partai politiknya. Situasi ini dapat didefinisikan bahwa setting produksi seorang figur politisi berawal dari perhatian publik dan seringkali meminjam langsung teknik-teknik dari 
selebriti di dunia hiburan; seperti pelawak, politikus yang dilatih, perlakuan yang berbeda, pemilihan kostum hingga ketelitian dalam pemolesan karakter. Dalam analisis isi berita politik terdapat aspek yang memiliki kesamaan dengan penekanan pada peran-peran sentral yang dimainkan dengan publisitas melalui "tradisi menjual popularitas atau kemasyuran" dalam usaha untuk melahirkan sosok politikus. Lihat Tabel I.

Berdasarkan hasil pengungkapan makna oleh informan, peneliti menggambarkan studi khalayak aktif, yang diposisikan sebagai pembaca yang berperan dalam pemaknaan teks. Pemaknaan ini merupakan proses menemukan makna-makna yang terpikirkan. Fokus studi resepsi ini pada proses decoding pembaca. Decoding merupakan proses penerimaan kodekode oleh pembaca teks. Hasil decoding sangat tergantung pada decoders sebagai entitas yang aktif dalam menciptakan makna teks. Pada akhirnya khalayak sangat aktif dalam menciptakan teks. Lihat Tabel 2.

Hasil resepsi menunjukkan bahwa Kode Persona cenderung pada pembacaan oposisi, kode Isi cenderung pada pembacaan Oposisi, kode transfer lebih pada pembacaan negosiasi, sementara kode partisipasi cenderung pada kelompok pembacaan negosiasi. Hasil pembacaan cenderung menolak berita dikatakan mendidik, meskipun hasilnya berimbang dengan kelompok yang negotiated. Hasil ini lebih mengarah Sindo dan Tempo sudah berpraktik pragmatis dalam pendidikan politik melalui kontruksi berita onlinenya.

Pemaknaan pembaca lebih lanjut menekankan bahwa implikasi dari situasi tersebut, adalah bagian dari sebuah cerita yang berlaku di manapun. Kondisi itu disebabkan oleh mapannya instalasi komersial dalam mekanisme industri untuk mengelola persepsi publik melalui media massa. Pengaruh dari 'smiling professions' dalam praktik jurnalisme tercermin melalui liputan beritanya dan menempatkannya sebagai elemen fundamental. Meskipun terdapat komponen lain dari cerita yang disajikan dalam liputan media massa. Namun telah terjadi pergeseran dalam pendekatan liputan politik yang menjurus pola yang sama dengan berita politik dalam media cetak mainstream. Pola yang dimaksud tersebut lebih merefleksikan adanya peningkatan terhadap fokus personal, perdebatan topik tertentu atas isu-isu mendasar, yang bersifat struktural dengan pendekatan-pendekatan tertentu. Bila kita menganalogikan pola ini dengan istilah "tabloidisasi", fokus pemberitaan yang serupa dengan format berita hiburan yang mulai diterapkan pada banyak liputan politik. Migrasi format berita politik ini terjadi beberapa tahun belakangan.

Gejala migrasi tersebut telah menjadi tren yang berulang dibanyak media massa, lebih jauh gejala ini timbul karena dorongan-dorongan untuk menggabungkan antara ranah politik dengan proses produksi selebriti. Pembenaran atas praktek ini bagi kalangan media adalah tidak sekedar 
Wahyuni Choiriyati, Manifestasi Pragmatisme Pendidikan Politik...

Tabel 1. Pemaknaan Isi Berita dan Kategori Berita

\begin{tabular}{|c|c|c|c|c|}
\hline Informan & $\mathrm{FN}$ & NR & WN & TN \\
\hline Latar belakang & $\begin{array}{l}\text { Jawa-Padang } \\
\text { Islam, } 38 \\
\text { tahun, S1, } \\
\text { menikah, } \\
\text { domisili } \\
\text { Jakarta, } \\
\text { konsumsi } \\
\text { media: Tempo } \\
\text { (online) }\end{array}$ & $\begin{array}{l}\text { Sunda, 22 } \\
\text { tahun, Islam, } \\
\text { S1, lajang, } \\
\text { domisili Bogor, } \\
\text { konsumsi } \\
\text { media: Tempo } \\
\text { (online) }\end{array}$ & $\begin{array}{l}\text { Jawa, } 52 \text { tahun, } \\
\text { Islam, menikah, } \\
\text { S3, domisili } \\
\text { Depok. } \\
\text { konsumsi } \\
\text { media: Sindo } \\
\text { (online) }\end{array}$ & $\begin{array}{l}\text { Betawi, } 20 \\
\text { tahun, } \\
\text { lajang,SMA, } \\
\text { domisili } \\
\text { Tangerang, } \\
\text { konsumsi } \\
\text { media: Sindo } \\
\text { (online) }\end{array}$ \\
\hline \multicolumn{5}{|c|}{ Pemaknaan Kategori Berita Selebriti Politisi } \\
\hline $\begin{array}{l}\text { Pemaknaan } \\
\text { pada politisi } \\
\text { selebriti } \\
\text { (kode: } \\
\text { Persona) }\end{array}$ & $\begin{array}{l}\text { Aji mumpung, } \\
\text { tidak } \\
\text { berkarakter, } \\
\text { tidak } \\
\text { kompeten dan } \\
\text { pemilih bukan } \\
\text { warga terdidik }\end{array}$ & $\begin{array}{l}\text { Punya uang dan } \\
\text { popular jadi } \\
\text { butuh status } \\
\text { baru "politikus" }\end{array}$ & $\begin{array}{l}\text { Sah saja, meski } \\
\text { kinerja rendah, } \\
\text { tidak produktif } \\
\text { karena bukan } \\
\text { wilayah profesi } \\
\text { nya }\end{array}$ & $\begin{array}{l}\text { Tidak tertarik } \\
\text { untuk } \\
\text { mencermati, yg } \\
\text { tidak } \\
\text { berpendidikan } \\
\text { politik pasti } \\
\text { lebih tdk } \\
\text { berkualitas }\end{array}$ \\
\hline $\begin{array}{l}\text { Isi berita } \\
\text { politik } \\
\text { (kode: isi) }\end{array}$ & $\begin{array}{l}\text { Dangkal, tidak } \\
\text { ada prestasi } \\
\text { dalam rekam } \\
\text { jejak nya. } \\
\text { kurang } \\
\text { memberi } \\
\text { manfaat bagi } \\
\text { masyarakat } \\
\text { luas }\end{array}$ & $\begin{array}{l}\text { Visi artis tidak } \\
\text { jelas, partai } \\
\text { hanya } \\
\text { menjadikan } \\
\text { sebagai vote } \\
\text { getter }\end{array}$ & $\begin{array}{l}\text { Jarang tertarik, } \\
\text { politisi banyak } \\
\text { tidak beretika, } \\
\text { bagaimana } \\
\text { dengan } \\
\text { selebriti. Gosip } \\
\text { isinya, ato } \\
\text { malah bukan } \\
\text { berita, lebih } \\
\text { banyak sensasi } \\
\text { minim prestasi }\end{array}$ & $\begin{array}{l}\text { Hampir sama } \\
\text { dengan } \\
\text { infotaimen dari } \\
\text { pada berita } \\
\text { politik }\end{array}$ \\
\hline $\begin{array}{l}\text { Peran media } \\
\text { online dalam } \\
\text { pendidikan } \\
\text { politik } \\
\text { (kode: } \\
\text { transfer) }\end{array}$ & $\begin{array}{l}\text { Menghibur } \\
\text { dan praktis. }\end{array}$ & $\begin{array}{l}\text { Strategis karena } \\
\text { selalu up date }\end{array}$ & $\begin{array}{l}\text { Harus follow } \\
\text { up karena } 1 \\
\text { berita kadang } \\
\text { tidak tuntas }\end{array}$ & $\begin{array}{l}\text { Anak muda } \\
\text { jarang mau up } \\
\text { date berita } \\
\text { politik, berita } \\
\text { dianggap } \\
\text { kurang strategis }\end{array}$ \\
\hline $\begin{array}{l}\text { Sosialisasi } \\
\text { pada } \\
\text { kesadaran } \\
\text { pemilih } \\
\text { (Kode: } \\
\text { partisipasi) }\end{array}$ & $\begin{array}{l}\text { Terbatas } \\
\text { karena waktu } \\
\text { untuk akses } \\
\text { tidak banyak }\end{array}$ & $\begin{array}{l}\text { Tidak } \\
\text { memungkinkan } \\
\text { untuk } \\
\text { partisipatif bagi } \\
\text { pekerja yang } \\
\text { mobilitas nya } \\
\text { tinggi }\end{array}$ & $\begin{array}{l}\text { Mengimbangi } \\
\text { media } \\
\text { mainstream krn } \\
\text { sering tidak } \\
\text { terkejar } \\
\text { materinya }\end{array}$ & $\begin{array}{l}\text { Tidak ada } \\
\text { sanksi politis, } \\
\text { jadi tidak } \\
\text { terlalu paham } \\
\text { arti partisipasi } \\
\text { untuk apa }\end{array}$ \\
\hline
\end{tabular}


Tabel 2. Pembacaan Teks

\begin{tabular}{llll}
\hline \multicolumn{1}{c}{ KODE } & \multicolumn{1}{c}{$\begin{array}{c}\text { Pembacaan } \\
\text { Dominan }\end{array}$} & \multicolumn{1}{c}{$\begin{array}{c}\text { Pembacaan } \\
\text { Negosiasi }\end{array}$} & Pembacaan Oposisi \\
\hline Persona & Informan NR & Informan WN & Informan FN, TN \\
Isi & - & Informan TN & Informan FN, WN, NR \\
Transfer & Informan FN, & Informan WN, TN & - \\
& NR & Informan FN, WN, Informan NR \\
Partisipasi & - & TN & \\
& & &
\end{tabular}

menjual sisi glamournya atau sekedar menghadirkan politikus spektakuler namun lebih mengimplikasikan bagaimana manajemen perencanaan media internalnya dalam praksis peran media massa terkait isu-isu politik dan aksesnya pada informasi politik.

Kajian internasional mengenai politikus dan selebriti yang dikonstruksi oleh media massa mendudukkan media massa sebagai agen yang berorientasi pada nilai-nilai kapitalisme dan komersialisasi informasi. Fusi yang dilakukan dalam format pemberitaan media dengan melibatkan artis dalam berita politik mengubah konfigurasi filosofi nilai politik. Esensi filosofi nilai politik telah direduksi menjadi formatformat pemberitaan yang bertajuk hiburan, dengan asumsi media memiliki agenda atas penonjolan isu politik berdasarkan pada perencanaan internalnya, bukan mengacu pada fungsi utama media massa selaku institusi yang bertanggung jawab dalam transmisi nilai-nilai luhur terkait pendidikan politik.

Sedangkan secara mikro, konteks realitas media nasional kita juga tidak jauh berbeda. Media massa kita melakukan praktek penggabungan format pemberitaan yang tidak berimbang dalam liputan politik versus politikus selebriti. Konstruksi media atas liputan politik cenderung mengadaptasi sisi prominence politisi selebriti dibandingkan kompetensi dan kredibilitasnya sebagai politikus. Media kita menunjukkan betapa telah terjadi kedangkalan dalam dunia politik yang disebabkan oleh perubahan atas nama formalitas demokrasi yang lebih berorientasi pada kepentingan privat ekonomi dan industri media yang menggerus esensi falsafah politik.

Kenyataan bahwa isi pesan media massa sering begitu halus sehingga tidak disadari khususnya oleh pembaca, mendorong munculnya kebutuhan akan Literasi Media sebagai metode atau langkah-langkah untuk memecahkan masalah ini. Literasi Media adalah kemampuan untuk mengkritik isi media dan memiliki pemahaman penuh tentang realitas. Masyarakat harus memiliki; kemampuan untuk mengakses media, menganalisis isi media sesuai dengan konteks, mengkritik media massa, dan menulis pesan mereka sendiri dalam berbagai bentuk dan jenis media. Literasi Media, pada gilirannya, dapat menjadi langkah antisipatif dalam menghadapi konflik serta menjaga perdamaian di suatu wilayah. Stuart 
Wahyuni Choiriyati, Manifestasi Pragmatisme Pendidikan Politik...

Hall (1973) mengungkapkan suatu analisis dari praktek media berdasarkan perspektif dari teori kulturalis Marxist, yakni dengan mengungkapkan otonomi media massa dan mengganti konsep Gramsci (hegemoni) serta Althusser (media sebagai ideological state apparatus) mengenai ideologi dominan dalam media (Woollacott, 1982).

Setelah reformasi, suhu politik kita semakin demokratis, hal ini diikuti oleh perilaku media yang semakin terbuka dan kompromi dengan pasar. Dalam sistem yang terbuka ini, popularitas menjadi prasyarat utama bagi siapa pun yang mau mencalonkan diri jadi pejabat publik atau anggota legislatif. Dalam konteks ini, kalangan selebriti dianggap mempunyai modal besar. Selebriti di sini mencakup para pesohor yang sering muncul di media massa, seperti bintang film, artis sinetron, penyanyi, bintang iklan, atau model terkenal.

Popularitas sebagai selebriti dalam film, sinetron atau sebagai musisi secara nyata mendongkrak tingkat kepercayaan rakyat. Kepercayaan semakin tinggi karena banyak rakyat yang telanjur kecewa dengan kinerja kepala daerah dari kalangan politisi, pengusaha, militer, atau birokrat yang gagal memperjuangkan aspirasi rakyat. Mengutip wawancara penulis dengan pakar Komunikasi Politik LIPI di lantai 11, Lili Romli pada 1 Desember 2015, dalam menanggapi lolosnya tujuh belas artis ke senayan periode 2014-2019, Romli menegaskan bahwa media memiliki andil dalam meloloskan mereka. Sejalan dengan fungsi imperatif bagi publiknya seharusnya media melaksanakan kontrol atas kinerja mereka, Romli menuturkan,

"...saya liat media yang memulai, yang mempopulerkan kan media juga menjunjung-junjung tentang figur-figur itu. Karena media massa yang memulai maka tentunya ketika mereka terpilih, media juga yang harus mengkritisi, mengenai apa yang telah mereka lakukan, bagaimana kinerja mereka. Harus mengkritisi, berimbang, harus bertanggung jawab, tidak boleh lepas tangan. Itulah tugas moralitas dari media massanya, jangan sampe tenggelam meliput hal-hal yang lain dan ini sebagai sebuah peringatan bahwa memasuki sebuah dunia politik bukan sesuatu hal yang mainmain...

Romli selaku pengamat politik LIPI yang melihat praktek pragmatisme tidak hanya menimpa industri media namun sudah menjadi sebuah pola pikir yang berkembang di masyarakat. Lebih lanjut hal ini dikarenakan tingkat rasionalitas masyarakat kita masih rendah. Keterpilihan publik figur salah satunya karena kondisi masyarakat kita masih terbelenggu kemiskinan. Jerat kemiskinan mengakibatkan daya nalar dan literasi tindakan politiknya menjadi rendah.

Keterlibatan media online dalam hal ini portal berita Tempo dan Sindo dipastikan dalam konstruksi citra selebriti dalam ranah politik merupakan bagian dari upaya pendangkalan infomasi politik. Dari hasil analisis permukaan yang dilakukan peneliti, keterlibatan Tempo dan Sindo dalam memberitakan kiprah artis berpolitik 
adalah bagian dari praktik mengkomersilkan informasi politik yang seharusnya mendidik. Persoalan politik dan perekonomian bangsa tidak akan dengan mudah diselesaikan dengan bermodal ketenaran. Untuk mengatasi persoalan ini dibutuhkan kompetensi, kredibilitas dan integritas atas kemampuan sorang kandidat politisi.

Wacana selebriti politisi yang banyak digulirkan oleh oleh portal berita kita, menjadi bagian menarik bagi peneliti untuk melihat sejauh mana manifestasi pragmatisme yang dilakukan media kita. Tentunya hasil penelitian ini tidak sepenuhnya mampu menghasilkan generalisasi atas peran media massa kita. Bagian kecil dari penelitian ini berupaya untuk menyadarkan masyarakat mengenai seberapa besar pengaruh media dalam opini khalayak. Kekuatan media terbukti mampu membangun citra seorang artis untuk menarik simpati masyarakat sebagai konstituennya.

\section{DISKUSI}

Paling tidak ada tiga komponen yang sangat berpengaruh dalam memaknai pemberitaan mengenai selebriti politisi, yaitu media massa, masyarakat umum dan politisi selebritis. Pekerjaan menjadi politisi bukanlah menjadi sesuatu yang dianggap sakral lagi di Indonesia pasca reformasi. Sistem pemilihan anggota legislative yang berdasarkan pada suara terbanyak membuat setiap orang berlomba-lomba menduduki jabatan publik tersebut. Kapasitas dan kapabilitas seseorang untuk bisa menduduki kursi anggota dewan tidak lagi menjadi unsur utama yang diperhatikan. Ukuran baru yang bahkan pada saat ini dianggap menjadi hal yang paling penting di Indonesia adalah tingkat popularitas. Kondisi ini yang membuat banyak selebriti yang biasa menjadi penghibur masyarakat di layar kaca beralih peran dan tugas menjadi perwakilan masyarakat di Senayan. Mereka terpilih dengan prosentase suara yang relative besar meskipun kemampuan mereka dalam dunia politik dan menyuarakan aspirasi masyarakat dengan menjadi anggota dewan belum jelas. Kemasyuran nama sebagai selebriti yang dikuatkan dengan exposure media massa terhadap masyarakat luas membuat mereka bisa memperoleh dukungan dari masyarakat.

Kebanyakan masyarakat di Indonesia belum paham betul mengenai perpolitikan. Tidak jarang mereka hanya mengenal nama calon karena telah terbiasa didengungkan. Bahkan pada pemilihan umum sebelumnya ketika digunakan foto calon, masyarakat awam hanya memilih berdasarkan rupa yang dianggap familiar, cantik atau tampan. Banyak selebriti Indonesia yang lolos untuk menduduki kursi di Senayan. Pendidikan politik yang seharusnya diterima masyarakat, nyatanya masih jarang dilakukan. Media massa yang diharapkan menjalankan fungsi pendidikan politik kepada masyarakat justru melalaikan fungsinya.

Kuasa kapitalisme melekat pada institusi media massa. Hal ini nampak dari pemberitaan yang hanya menjual sensasi dan jauh dari unsur mendidik. Pemberitaan politik yang sebelumnya 
Wahyuni Choiriyati, Manifestasi Pragmatisme Pendidikan Politik...

menggunakan format khas yangs serius dan mendalam sekarang lebih ke arah format tabloid seperti dalam pemberitaan politisi selebriti. Pemberitaan politisi selebriti bukan menyoroti upaya melakukan pendidikan politik bagi masyarakat luas. Pemberitaan selebritisi politisi tidak memberikan gambaran yang signifikan terkait upaya mendidik masyarakat luas untuk bisa menentukan calon mana yang paling layak untuk dipilih. Pemberitaan mengenai selebriti politisi cenderung mengungkapkan kehidupan personal selebriti. Kondisi ini menggambarkan bahwa institusi media massa menjadikan pemberitaan mengenai politisi selebriti sebagai komoditas untuk bisa mendatangkan keuntungan. Masyarakat Indonesia dengan tingkat literasi media yang masih rendah cenderung mengonsumsi tayangan yang justru sarat sensasi dan jauh dari edukasi. Pada titik ini kapitalisme membuat media massa pragmatis dalam memproduksi pemberitaan yang justru semakin jauh dari upaya melakukan pendidikan politik bagi masyarakat luas. Pada akhirnya sebagian besar masyarakat akhirnya juga berpikir pragmatis dan hanya sedikit yang sadar dengan upaya membanalkan nalar dan rasio masyarakat Indonesia.

\section{KESIMPULAN}

Dipilihnya Tempo dan Sindo Online menjadi teks sekunder dalam memaknai berita selebriti politisi karena aspek keterwakilan dua media tersebut dari sisi keterbacaan. Beberapa berita yang dipilih melampaui angka 1.500 klik pembaca online. Ini artinya pembaca banyak merujuk pada informasi yang disampaikan oleh Sindo dan Tempo. Ternyata penguasaan media menjadi modal penting, dalam riset ini ditemukan bahwa media nasional kita beberapa diantaranya melakukan pencitraan atas peran tersebut. Hal ini menjadi pergulatan antara kepentingan media selaku lembaga edukasi politik dan sebaliknya menjadi agen pencitraan atas peran politik yang semakin dangkal. Pendangkalan inilah merupakan embrio dari normalisasi kekuatan konstruksi berita yang berujung ke arah pragmatisme. Pernyataan ini inheren berdasarkan analisis resepsi, pembaca menyatakan bahwa liputan seputar artis menjadikan khalayak selaku pembaca sekaligus pengkonstruksi realitas merasa artis sahsah saja berpolitik sebagai perwujudan hak warga negara. Apalagi, jika mereka didukung pengalaman, kemampuan, serta mau belajar saat ketika terpilih nanti. Karenanya bisa memunculkan pemerintahan yang baik. Namun, fenomena yang merebak sekarang masih cenderung dalam pencitraan politik tanpa isi dan dangkal. Mengingat sebagian partai masih mencalonkan artis karena popularitas saja tanpa melihat kompetensinya.

\section{DAFTAR PUSTAKA}

Turner, Graeme. (2004). Understanding Celebrity. Londong: Sage Publications

Bone, Hugh. A and Austin Ranney. (1976). Politics and Voters. New York: McGraw-Hill 
Schickel, Richard. (1985). Intimate Strangers: The Culture of Celebrity. New York: Doubleday

Firmanzah.(2007). Marketing Politik, Jakarta: Yayasan Obor Indonesia

Robert, Robertus dan Agustinus R. (2008). Filsafat yang Mencari Politik. Dalam Rocky Gerung. Kembalinya Politik: Pemikiran Politik Kontemporer dari (A) Rendt sampai (Z)izek. Jakarta: Perhimpunan Pendidikan Demokrasi (P2D) dan Marjin Kiri

Littlejohn, Stephen W., (1996). Theories of Human Communication. Fifth Edition, Belmont-California: Wadsworth

Dewey, William John.( 1974). Progress and Pragmatism. London: Greenwood

Branston, Gill and Roy Stafford. (2006). The Media Student's Book. Fourth Edition. London: Routledge

Wyatt, Justin. (1994). High Concept: Movies and Marketing in
Hollywood. Austin: University of Texas Austin.

Mosco, Vincent. (1996). The Political Economy of Communication. London: Sage Publication

Hall, Stuart (1973). Encoding and Decoding in the Television Discourse. Birmingham: Centre for Contemporary Cultural Studies.

Denzin, NK. Dan Lincoln, YS. (1994). Handbook of Qualitative Research. London: Sage Publication

Woollacott, Janet. (1982). 'Messages and meanings'. dalam Gurevitch, Michael (ed). Culture, society and the media. London: Routledge

Flick, Uwe., Ernst von Kardoff, and Ines Steinke. (2004). A Companion to Qualitative Research. London: SAGE Pubication. 